A.A. Mohamad Yusoff, K.A. Ahmad, S.N. Sulaiman, Z. Hussain, N. Abdullah

\title{
AIR CAVITY-BASED VIBRATIONAL PIEZOELECTRIC ENERGY HARVESTERS
}

\begin{abstract}
Introduction. Known vibrational energy harvesting methods use a source of vibration to harvest electric energy. Piezoelectric material works as a sensing element converted mechanical energy (vibration) to electrical energy (electric field). The existing piezoelectric energy harvesting (PEHs) devices have low sensitivity, low energy conversion, and low bandwidth. The novelty of the proposed work consists of the design of PEH's structure. Air cavity was implemented in the design where it is located under the sensing membrane to improve sensitivity. Another novelty is also consisting in the design structure where the flexural membrane was located at the top of electrodes. The third novelty is a new design structure of printed circuit board (PCB). The purpose of improvised design is to increase the stress in between the edges of PEH and increase energy conversion. With the new structure of $P C B$, it will work as a substrate that absorbs surrounding vibration energy and transfers it to sensing element. Methods. Three techniques were successfully designed in PEH and fabricated namely PEH A, PEH B, and PEH C were characterized by two experiments: load and vibration. The load experiment measured load pressure towards the PEH, whereas the vibration experiment measured stress towards the PEH. Results. PEH C has the highest induced voltage for a weight of $5.2 \mathrm{~kg}$ at the frequency of $50 \mathrm{~Hz}$ and the highest stored voltage for a period of $4 \mathrm{~min}$. The three techniques applied in PEHs were showed improvement in transducer sensitivity and energy conversion. Practical value. A piezoelectric acoustic generator was used in the experiment to compare the performance of the designed PEH with available piezoelectric transducers in the market. The new flexible membrane worked as a sensing element was worked as a cantilever beam. PVDF was used as a sensing element due to the flexibility of the polymer material, which is expected to improve sensitivity and operating bandwidth. References 21, tables 6, figures 19.
\end{abstract}

Key words: piezoelectric energy harvester, air cavity, flexural membrane.

Вступ. Відомі методи збору вібраційної енергії використовують джерело вібрачії для збору електричної енергії. П'єзоелектричний матеріал прачює як чутливий елемент, перетворюючи механічну енергію (вібрацію) в електричну енергію (електричне поле). Існуючі пристрої збору п'єзоелектричної енергії (ЗПЕ) мають низьку чутливість, низьке перетворення енергії і малу смугу пропускання. Новизна запропонованої роботи полягає в проектуванні конструкиії ЗПЕ. У конструкиї реалізована повітряна порожсниа, яка розташована під чутливої мембраною для підвищення чутливості. Ще один елемент новизни полягає в конструкиїі, в якій вигиниста мембрана розташована у верхній частині електродів. Третя новизна - ие нова конструкиія друкованої плати. Мета запропонованої конструкиії - збільшити механічну напругу між краями ЗПЕ і підвищити перетворення енергії. Завдяки новій конструкції друкованої плати вона буде працювати як підкладка, яка поглинає навколишню енергію вібрації і передає ї̈ на чутливий елемент. Методи. Три методи були успішно використані для проектування ЗПЕ, $і$ відповідно названі виготовлені ЗПЕ А, ЗПЕ Б $і$ ЗПЕ В були описані двома експериментальними характеристиками: навантаження $і$ вібрація. В експерименті з навантаженням вимірювався тиск навантаження на ЗПЕ, в той час як в експерименті з вібрацією вимірювалася механічна напруга на ЗПЕ. Результати. ЗПЕ В має найвищу індуковану напругу для ваги 5,2 кг при частоті 50 Ги і найвищу збережену напругу протягом 4 хвилин. Три методи, що застосовуються для ЗПЕ, показали поліпшення чутливості перетворювача і перетворення енергії. Практична цінність. В експерименті використовувався п'єзоелектричний акустичний генератор для порівняння характеристик розробленого ЗПЕ з доступними на ринку п'єзоелектричними перетворювачами. Нова гнучка мембрана прачювала як чутливий елемент, щзо представляв собою консольну балка. В якості чутливого елемента використовувався полівініліден фторид завдяки гнучкості полімерного матеріалу, який, як очікується, поліпшить чутливість і робочу смугу пропускання. Бібл. 21, табл. 6, рис. 19.

Ключові слова: збирач п'єзоелектричної енергії, повітряна порожнина, вигиниста мембрана.

Introduction. Energy harvesting is a process to collect and store energy from energy sources, such as wind [1], solar [2], thermal [3], vibration [4], and biomechanical [5] sources. The facilities for harvesting wind, solar, and thermal energy are designed in huge sizes and generate high energy, whereas the components for harvesting vibration and biomechanical energy are designed in small sizes and sometimes generate energy in microvolts only. Vibration is an energy source that can be harvest at any place. Among the examples are vibration energy created by bridges [6], machines [7, 8], compressors [9], airport walkways [10] and railway tracks [11]. These vibrational energy sources are wasted if not harvested. Two methods that can harvest vibration energy are electromagnetic energy harvesters (EEHs) [9, 10] and piezoelectric energy harvesters (PEHs) $[10,11]$. The basic components of an EEH consist of a spring, a coil, and a permanent magnet.

A vibrational force is applied to the spring to make it swing and the permanent magnet moves through the coil. An induced voltage is generated by the coil during the movement of the permanent magnet through the coil [12]. Some design has used a ring to replace the spring to make the permanent magnet move freely [13]. However, these designs suffer from the limitation of ageing, such as a spring loses its stiffness with time and a permanent magnet also loses its magnetization with time. Hence, PEHs are used to solve these problems [14]. A PEH consists of a piezoelectric material, a cantilever beam, and a proof mass. The piezoelectric material is a sensing element to convert mechanical energy to electrical energy. It was attached together with cantilever beam which is worked as a swinging component. Proof mass was placed at the end of the cantilever worked as a load that makes the cantilever beam swing after a vibration force is acted to the cantilever. When the cantilever beam swings, it causes stress inside the sensing material; subsequently, an induced voltage is generated.

PEH consists of the cantilever beam and the proof mass was free at the end and mounted beneath its base, which is known as base-mounted piezoelectric (BMP) cc A.A. Mohamad Yusoff, K.A. Ahmad, S.N. Sulaiman, Z. Hussain, N. Abdullah 
harvesters. A BMP harvester with a $0.267 \mathrm{~mm}$ thick layer of PZT5H was attached to a polymer beam $(1.6 \mathrm{~mm} \times 4.9 \mathrm{~mm}$ $\times 20.0 \mathrm{~mm})$ and a steel tip mass. The peak voltages increased to $6.20,15.1,29.2$, and $54.3 \mathrm{~V}$ with resonant frequencies of $45 \mathrm{~Hz}$ at $0.25 \mathrm{~g}$ to $44 \mathrm{~Hz}$ at $1 \mathrm{~g}$. Shorter beams were preferred in the design to improve electromechanical coupling and generate more induced voltage [15]. A cantilever beam consisted of a sensing element called piezoelectric bimorph and an electrode called copper with the dimension of $79 \mathrm{~mm} \times 1.55 \mathrm{~mm}$ (length $\times$ thickness) and attached to the proof mass with the dimension of $20 \mathrm{~mm} \times 4 \mathrm{~mm}$ (length $\times$ thickness). This device generated an induced voltage of $37 \mathrm{~V}$ and output power at $145 \mathrm{~Hz}$. It was installed under a smart road system [16]. For a low mechanical damping ratio, a vacuum package energy harvester (VPH) was designed to cater the problem of $50 \%$ power drop, corresponding to $2 \%$ deviation of frequency. The VPH was similar to the design previously which was consisted of a piezoelectric bimorph with the dimension of $28.6 \times 12.7 \times 0.508 \mathrm{~mm}^{3}$ and stiffness of $K=760 \mathrm{~N} / \mathrm{m}$. The VPH generated output power of $90.3 \mu \mathrm{W}$ at the frequency of $50 \mathrm{~Hz}$ [17].

A multi-degree of freedom vibration system has been added in the design of PEHs to improve the wideband performance. This design offers high power density and increases the generated induced voltage. Three proof masses were located at the centre, top left, and bottom right. Then, the cantilevers were attached to the mass centre, top left mass, and bottom right mass. The bandwidths were increased to $5.3,9.8,14$, and $16 \mathrm{~Hz}$ for the acceleration of $0.2,0.5,0.7$, and $1 \mathrm{~m} / \mathrm{s}^{2}$, respectively. The average power harvested by the PEHs were $0.34-2.80 \mu \mathrm{W}$ [18]. Two parallel beam structures were designed to improve the operating bandwidth of PEH. Each beam consisted of a top electrode and a bottom electrode, then a zinc oxide $(\mathrm{ZnO})$ was a sensing element with a thickness of $2.73 \mu \mathrm{m}$ sandwiched between the electrodes. This PEH generated an induced voltage of $18 \mathrm{~V}$ at the frequency of $142 \mathrm{~Hz}$ with a bandwidth of $15 \mathrm{~Hz}$ [19]. A cantilever beam was sandwiched with two sensing element and one end of the cantilever beam was installed with a tip mass, whereas the other end was nailed to the wall. The PEHs generated an average power of $25 \mu \mathrm{W}$ at the frequency range of $33-35 \mathrm{~Hz}$ [20]. This type of design can be applied for slow swinging movement.

The goal of the paper is to design a new flexible membrane worked as sensing element called piezoelectric polymers, polyvinylidene fluoride (PVDF) were attached together with a printed circuit board (PCB) and it was worked as a cantilever beam. PVDF was used as a sensing element due to the flexibility of the polymer material, which is expected to improve sensitivity and operating bandwidth. A PEH with good sensitivity can generate a high induced voltage. A new technique of substrate, PCB was used to absorb impact of surrounding vibration and transfer it to flexible sensing element which to improve sensitivity and bandwidth.

Subject of investigations. The PEH design focused on the design of the electrode circuit. Figure 1 shows the interdigitated electrode (IDE) circuit designed on a PCB. The IDE circuit consists of the IDE finger, the IDE path, and a terminal pad. The IDE finger used generated an induced voltage together with the sensing element, PVDF. Then, the IDE path lays the current to the terminal pad.
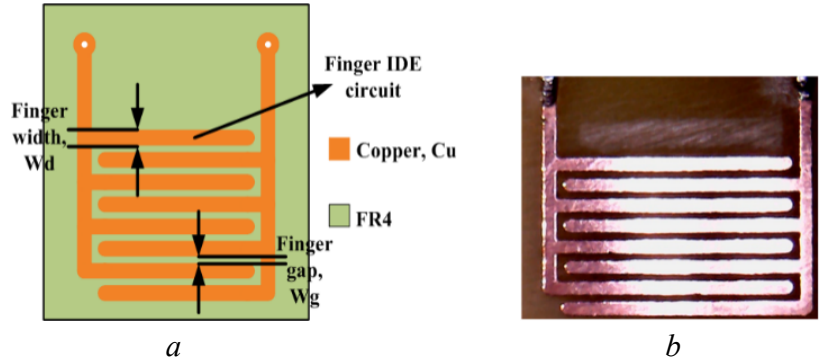

Fig. 1. IDE design circuit on a PCB: (a) schematic diagram and $(b)$ digital microscope image of the IDE circuit on a PCB

Three different electrode finger widths were fabricated and the width of electrode fingers were $0.5,1$, and $2 \mathrm{~mm}$. The gap between the electrode fingers for all designs was fixed to $0.5 \mathrm{~mm}$ and the number of electrode finger pairs was 4 . Three fabricated designs were namely PEH A, PEH B, and PEH C. They are shown in Table 1.

Table 1

Parameters of the IDE circuit for PEH A, PEH B, and PEH C

\begin{tabular}{|c|c|c|c|}
\hline PEH design & $\begin{array}{c}\text { Finger width, } \\
W_{d}, \mathrm{~mm}\end{array}$ & $\begin{array}{c}\text { Finger gap, } \\
W_{g}, \mathrm{~mm}\end{array}$ & Area of PVDF, $\mathrm{mm}^{2}$ \\
\hline $\mathrm{A}$ & 0.5 & \multirow{3}{*}{0.5} & 142.5 \\
\hline $\mathrm{B}$ & 1 & & 218.5 \\
\hline $\mathrm{C}$ & 2 & & 370.5 \\
\cline { 1 - 1 } & & &
\end{tabular}

The IDE design constructed using Proteus software is shown in Fig. 2.

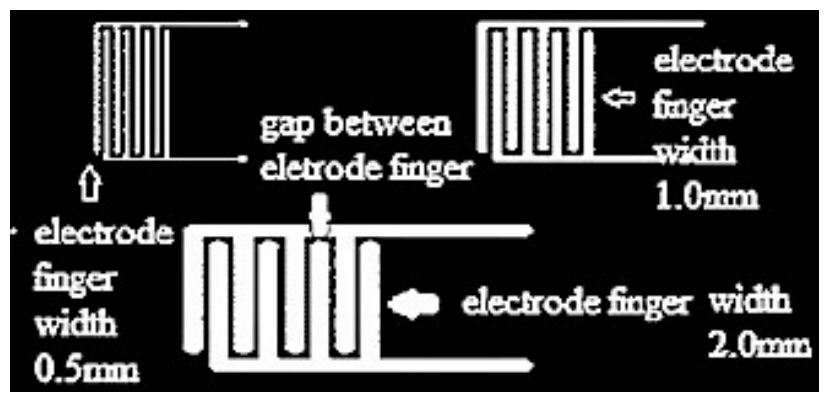

Fig. 2. IDE circuit design constructed using Proteus

$D_{33}$ mode piezoelectric energy harvester. The new design structure of PEH using the method of $d_{33}$ mode piezoelectric material was implemented in the design. The first number of $d_{33}$ mode indicates the voltage generated at $z$-axis and the second number indicates the force applied to the piezoelectric material that causes stress inside the piezoelectric material. A new design structure applied in PEH was the flexible sensing element placed at the top IDE electrode. The substrate of PEH was PCB used to absorb surrounding vibration energy and transfer to flexible sensing element, thus the sensing element got stress and converted to electric field. $D_{33}$ component inside sensing element was converted two times energy compared to $d_{31}$ mode.

Two new techniques approach, (1) flexible sensing element on top of electrode, and (2) substrate made of PCB were improved energy conversion and sensitivity. The operation of $d_{33}$ mode piezoelectric material on the PEH is shown in Fig. 3. 


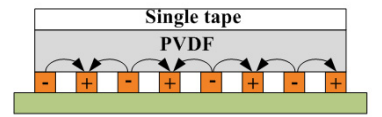

$a$

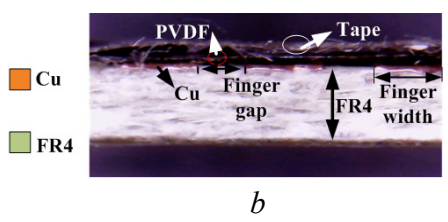

$b$
Fig. 3. $D_{33}$ mode piezoelectric energy harvester:

(a) schematic diagram and (b) cross-sectional digital microscope image of the PEH

The operation of $d_{33}$ mode polarization is that when stress occurs between the electrodes in three directions, polarization is also created between the electrodes in three directions. The electron $e$ moves from low potential (negative terminal) to high potential (positive terminal) and the movement of electrons induces voltage, as shown in Fig. 3, $a$. Figure 3, $b$ illustrates the cross-section of the $\mathrm{PEH}$, where the top of the PEH is a single tape, followed by PVDF, a row of copper and air space, and lastly the FR4. The new design structure of backing layer called air cavity was placed under sensing element and in between of finger electrodes. When the cantilever beam moves up and down, more stress occurs at the sensing element at cavity side and generated more induced voltage, as illustrated in Fig. 4.

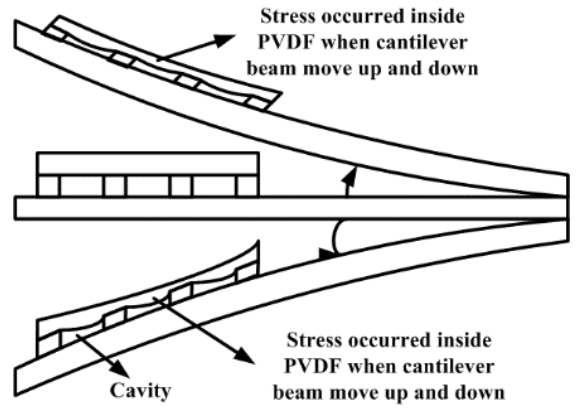

Fig. 4. Schematic diagram of stress occurring inside PVDF during the movement of the cantilever beam

Development of readout circuitry. The induced $\mathrm{AC}$ voltage accumulates at the terminal of $\mathrm{PEH}$, and then the readout circuitry is rectified, filtered, and stored the DC voltage in a capacitor. Figure 5 shows the schematic diagram of the parallel synchronized switching harvesting inductor circuit (SSHI) readout circuit introduced by [21], which consisted of the PEH, a switch (S), an inductor (L) of $22 \mu \mathrm{H}$, bridge diodes (D1 - D4) of Schottky type, a capacitor (C) of $12 \mathrm{nF}$, and resistor of $600 \mathrm{k} \Omega$. The maximum working voltage for the capacitor is $35 \mathrm{~V}$. A multimeter was used to measure the output DC voltage at $V_{c}(t)$. Diodes D1 to D4 worked as full-wave rectifiers to rectify all $\mathrm{AC}$ to $\mathrm{DC}$.

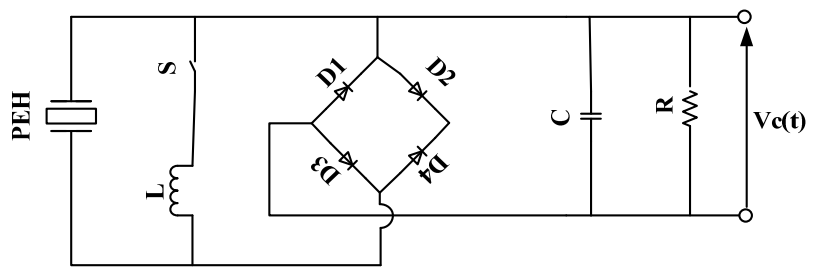

Fig. 5. Schematic diagram of a parallel SSHI readout circuit for energy harvesting

Fabrication. The overview of the fabrication process is shown in Fig. 6.

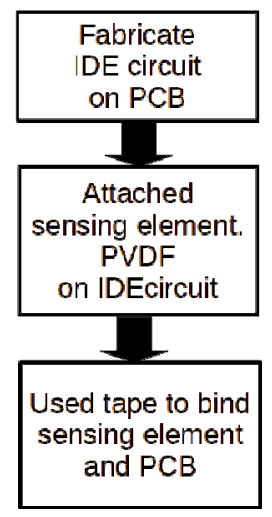

Fig. 6. Flowchart of the fabrication process

The steps presented in Fig. 6 were the flow of PEH fabrication. First, the IDE circuit was fabricated on a PCB, as shown in Fig. 7. Next, a PCB was cleaned using a brushing machine. The final step of the fabrication process was attaching PVDF on top of the fabricated IDE circuit using $3 \mathrm{M}$ single tape. The terminal pad was soldered with two wires and the completed fabricated PEH is shown in Fig 8.

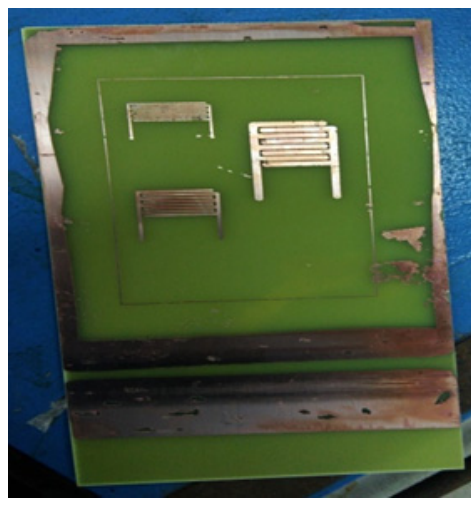

Fig. 7. Fabricated IDE circuits

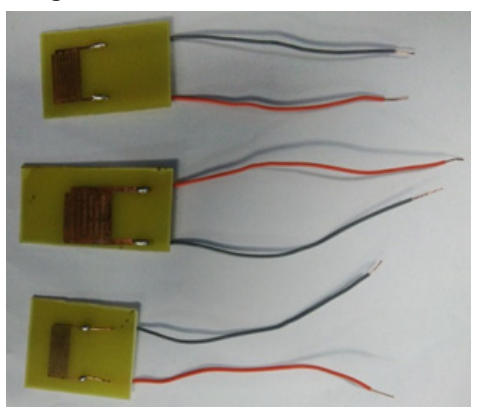

Fig. 8. Fabricated piezoelectric energy harvesters

Experimental setup. The PEH was characterized using load and vibration experiments. The load experiment measured load pressure towards the $\mathrm{PEH}$, whereas the vibration experiment measured stress towards the PEH. A piezoelectric acoustic generator was used in the experiment to compare the performance of the designed $\mathrm{PEH}$ with available piezoelectric transducers in the market. The parameters of the piezoelectric acoustic generator are listed in Table 2 .

Table 2

Diameter and area of the piezoelectric acoustic generator

\begin{tabular}{|c|c|}
\hline Parameter & Value \\
\hline Diameter of piezo ceramic, $\mathrm{mm}$ & 20 \\
\hline Area of piezo ceramic, $\mathrm{mm}^{2}$ & 314.16 \\
\hline
\end{tabular}


Figure 9 presents the piezoelectric acoustic generator. The diameter of the piezoelectric ceramic was $20 \mathrm{~mm}$, which was sandwiched between two copper layers.

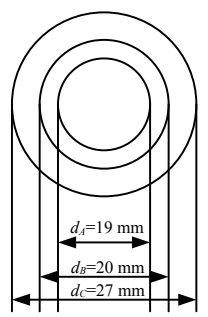

$a$

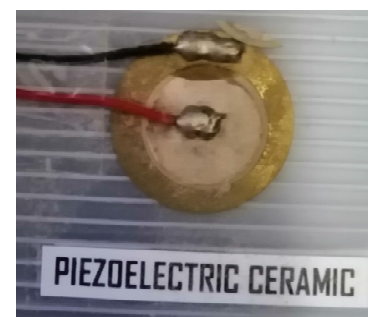

b
Fig. 9. Illustration of a piezoelectric acoustic generator: (a) schematic diagram and (b) camera image

Load experiment. The experiment was carried out by obtaining the output from different mass ranges of $200 \mathrm{~g}$ to $5.2 \mathrm{~kg}$ with a step of $1 \mathrm{~kg}$ placed on top of the $\mathrm{PEH}$. The study investigated the induced voltage for different weights and designs of PEHs. The equation for pressure $P$ in load experiment is:

$$
P=f / A,
$$

where $f$ is the gravitational force; and $A$ is the area of PVDF surface.

The equation of gravitational force is:

$$
f=m \cdot g
$$

where $m$ is the mass; $g$ is the gravity acceleration $\left(9.81 \mathrm{~m} / \mathrm{s}^{2}\right)$.

Six different weights were used: $200 \mathrm{~g}, 1.2 \mathrm{~kg}, 2.2 \mathrm{~kg}$, $3.2 \mathrm{~kg}, 4.2 \mathrm{~kg}$, and $5.2 \mathrm{~kg}$. The load experiment is shown in Fig. 10. Figure 10, $a$ shows the schematic diagram of the load experiment setup; Fig. 10, $b$ shows the use of $200 \mathrm{~g}$ and $1 \mathrm{~kg}$ loads. Meanwhile, Fig. 10,c shows the DC voltage measurement setup using a digital multimeter and an energy harvester circuit.
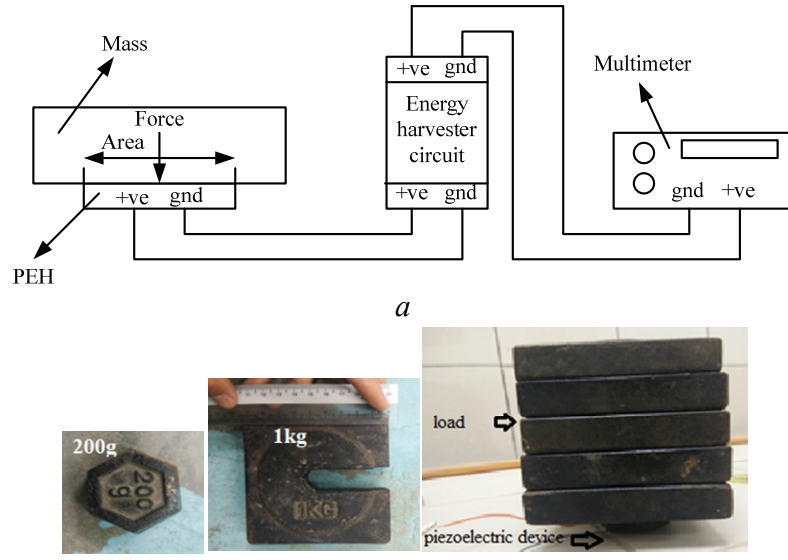

$b$

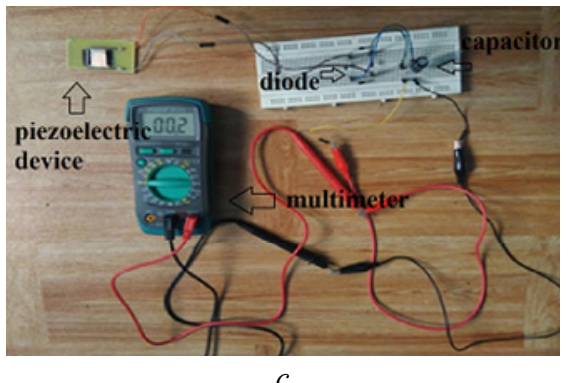

Fig. 10. Load experiment setup: (a) schematic diagram; (b) $200 \mathrm{~g}$ and $1 \mathrm{~kg}$ loads; (c) DC voltage measurement setup at the output of the energy harvester circuit using a digital multimeter
For load experiment, the loads were placed on the $\mathrm{PEH}$ and the output of the PEH was rectified and stored in a capacitor using an energy harvester circuit. The output of the energy harvester circuit was measured using a digital multimeter. For every measurement of load, three readings were recorded and the average reading for each load was recorded in a table.

Vibration experiment. The experiment was carried out by placing the PEH on a vibration machine. This experiment investigated the induced voltage generated by the $\mathrm{PEH}$ during vibration. A sieve shaker was used as a vibrator machine at $50 \mathrm{~Hz}$ and the $\mathrm{AC}$ voltage of the $\mathrm{PEH}$ output was measured using an oscilloscope. The vibration experiment setup is presented in Fig. 11.

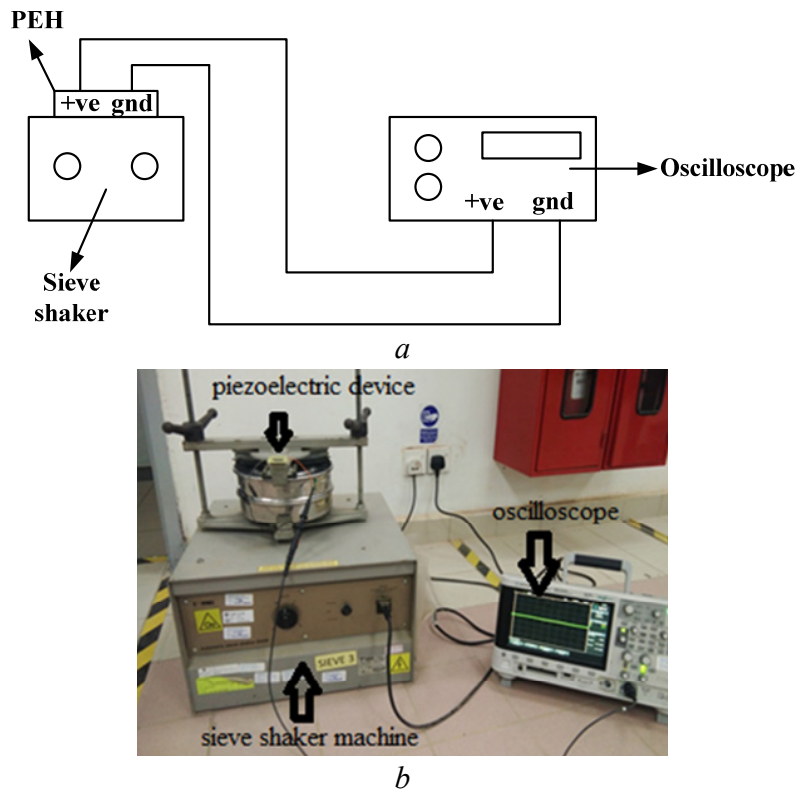

Fig. 11. Vibration experiment setup: (a) schematic diagram and (b) digital image of vibration experiment setup

Three different designs of PEHs were investigated in this experiment. A sieve shaker was set at $4 \mathrm{~min}$ of vibration and the generated AC output voltage of the $\mathrm{PEH}$ was recorded every minute. Two parts of measurement were conducted in this experiment, namely the measurement of the generated voltage versus input frequency and the measurement of the generated voltage for a period of time. The input frequency was set to $50 \mathrm{~Hz}$ because almost all vibration equipment in Malaysia used $50 \mathrm{~Hz}$ as an input of the machine.

Results and discussion. This section is divided into two parts, which are induced DC output voltage from load experiment and induced AC output voltage from vibration experiment. Both parts are discussed in terms of the performance of output voltage produced by the PEH.

DC output voltage from load experiment. The DC output voltage for all $\mathrm{PEH}$ designs (PEH A, PEH B, and $\mathrm{PEH} \mathrm{C}$ ) with different mass ranges of $0.2 \mathrm{~g}$ to $5.2 \mathrm{~kg}$ was measured and the mean values of the recorded voltage are shown in Table 3, 4, 5, respectively. Each table presents the weight, mean output voltage, and standard error for the particular design. The mean output voltage was calculated from three readings of the same weight measurement and divided by the number of readings. For this experiment, three readings were taken for calculating the mean output 
value and the standard error was a standard deviation of the mean value. The pressure was calculated from the input weight and area of PVDF.

Table 3

Results for PEH A

\begin{tabular}{|c|c|c|c|}
\hline $\begin{array}{c}\text { Weight, } \\
\mathrm{kg}\end{array}$ & $\begin{array}{c}\text { Mean output, } \\
\text { voltage, } \mathrm{mV}\end{array}$ & $\begin{array}{c}\text { Standard } \\
\text { error, } \%\end{array}$ & $\begin{array}{c}\text { Pressure, } \\
f / A, \mathrm{~N} / \mathrm{m}^{2}\end{array}$ \\
\hline 0.2 & 0.202 & 5 & 1401.43 \\
\hline 1.2 & 0.402 & 6 & 8408.57 \\
\hline 2.2 & 0.607 & 3 & 15415.71 \\
\hline 3.2 & 0.810 & 4 & 22422.86 \\
\hline 4.2 & 1.097 & 5 & 29430 \\
\hline 5.2 & 1.123 & 3 & 36437.14 \\
\hline
\end{tabular}

The standard error for all readings is acceptable because the error is less than $10 \%$. The highest standard error of $6 \%$ was recorded for the load weight of $1.2 \mathrm{~kg}$. The mean induced voltage increased proportionally with the input pressure given by load weight. Figure 12 shows that at the pressure of 29430 to $36437.14 \mathrm{~N} / \mathrm{m}^{2}$, the mean output voltage was saturated at $1.123 \mathrm{mV}$. The mean output from 0.202 to $1.097 \mathrm{mV}$ was proportional with the increase of pressure from 1400 to $29430 \mathrm{~N} / \mathrm{m}^{2}$, respectively.

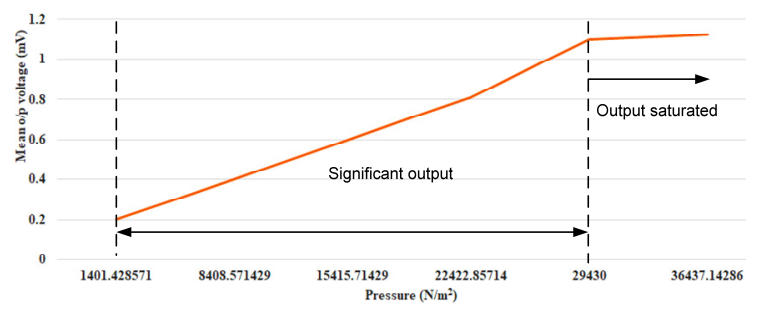

Fig. 12. Plot of mean output value versus pressure for PEH A

The results for PEH B are tabulated in Table 4. The readings are also acceptable because the standard error is less than $10 \%$. The input pressure started at a lower value of $897.94 \mathrm{~N} / \mathrm{m}^{2}$ compared to PEH A of $1401.429 \mathrm{~N} / \mathrm{m}^{2}$ and until the final load of $\mathrm{PEH} \mathrm{B}$, the input pressure was less than the final load of PEH A.

Results for PEH B

\begin{tabular}{|c|c|c|c|}
\hline $\begin{array}{c}\text { Weight, } \\
\mathrm{kg}\end{array}$ & $\begin{array}{c}\text { Mean output, } \\
\text { voltage, } \mathrm{mV}\end{array}$ & $\begin{array}{c}\text { Standard } \\
\text { error, } \%\end{array}$ & $\begin{array}{c}\text { Pressure, } \\
\text { flA, N/m }\end{array}$ \\
\hline 0.2 & 0.306 & 2 & 897.94 \\
\hline 1.2 & 0.904 & 3 & 5387.64 \\
\hline 2.2 & 1.103 & 3 & 9877.35 \\
\hline 3.2 & 1.303 & 5 & 14367.05 \\
\hline 4.2 & 2.004 & 4 & 18856.75 \\
\hline 5.2 & 2.301 & 5 & 23346.45 \\
\hline
\end{tabular}

Figure 13 shows a significant output voltage because the mean output voltage from the range of 0.306 to $2.301 \mathrm{mV}$ increased proportionally with the input pressure from 897.94 to $23346.45 \mathrm{~N} / \mathrm{m}^{2}$. The mean output voltage of PEH B was higher than PEH A for the low pressure input. It is shown that $\mathrm{PEH} \mathrm{B}$ is more sensitive and generated more induced voltage than PEH A.

Table 5 shows the tabulated results for PEH C. The mean output voltage was generated in the range of 0.7 to $2.5 \mathrm{mV}$ for the pressure range of 529 to $13768 \mathrm{~N} / \mathrm{m}^{2}$. The standard error shows that the readings are in the acceptable range for $\mathrm{PEH} \mathrm{C}$.

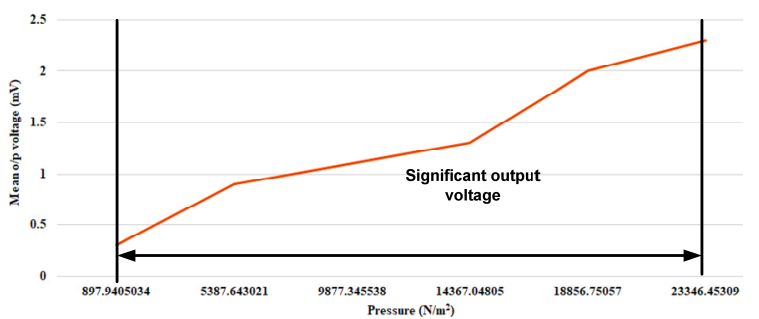

Fig. 13. Plot of mean output voltage versus pressure for PEH B

Table 5

Results for PEH C

\begin{tabular}{|c|c|c|c|}
\hline $\begin{array}{c}\text { Weight, } \\
\mathrm{kg}\end{array}$ & $\begin{array}{c}\text { Mean output, } \\
\text { voltage, } \mathrm{mV}\end{array}$ & $\begin{array}{c}\text { Standard } \\
\text { error, } \%\end{array}$ & $\begin{array}{c}\text { Pressure, } \\
f / A, \mathrm{~N} / \mathrm{m}^{2}\end{array}$ \\
\hline 0.2 & 0.702 & 3 & 529.55 \\
\hline 1.2 & 0.903 & 4 & 3177.33 \\
\hline 2.2 & 1.199 & 3 & 5825.10 \\
\hline 3.2 & 1.504 & 3 & 8427.87 \\
\hline 4.2 & 1.901 & 5 & 11120.65 \\
\hline 5.2 & 2.502 & 5 & 13768.42 \\
\hline
\end{tabular}

Figure 14 shows that $\mathrm{PEH} \mathrm{C}$ is more sensitive compared to $\mathrm{PEH} \mathrm{B}$ and PEH A. The low pressure input generated high induced voltage. $\mathrm{PEH} \mathrm{C}$ has the widest IDE electrode finger width, followed by $\mathrm{PEH} \mathrm{B}$ and $\mathrm{PEH} \mathrm{A}$. Furthermore, the highest generated induced voltage was obtained by PEH C, followed by PEH B and PEH A. Therefore, the width of finger electrodes improved the generated induced voltage and sensitivity of PEH.

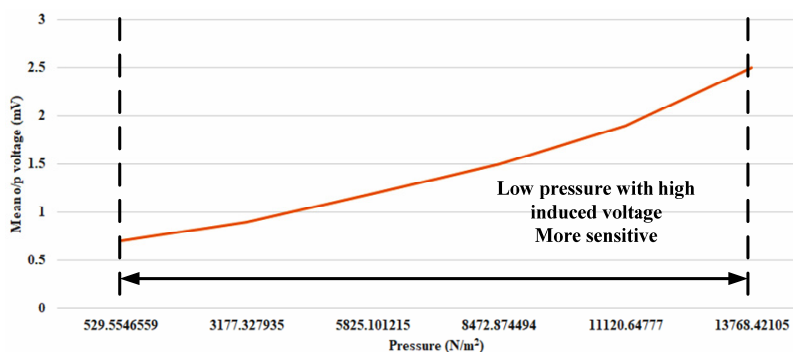

Fig. 14. Plot of mean output voltage versus pressure for PEH C

Table 6 tabulates the results for the commercial piezoelectric acoustic generator. The mean output voltage generated by the piezoelectric acoustic generator was in the range of 0.124 to $0.365 \mathrm{mV}$ for the range of input pressure input of $6248 \mathrm{~N} / \mathrm{m}^{2}$ to $162458.6 \mathrm{~N} / \mathrm{m}^{2}$.

Table 6

Results for piezoelectric acoustic generator

\begin{tabular}{|c|c|c|c|}
\hline $\begin{array}{c}\text { Weight, } \\
\mathrm{kg}\end{array}$ & $\begin{array}{c}\text { Mean output, } \\
\text { voltage, } \mathrm{mV}\end{array}$ & $\begin{array}{c}\text { Standard } \\
\text { error, } \%\end{array}$ & $\begin{array}{c}\text { Pressure, } \\
f / A, \mathrm{~N} / \mathrm{m}^{2}\end{array}$ \\
\hline 0.2 & 0.124 & 3 & 6248.41 \\
\hline 1.2 & 0.185 & 2 & 37490.45 \\
\hline 2.2 & 0.191 & 2 & 68732.48 \\
\hline 3.2 & 0.212 & 2 & 99974.52 \\
\hline 4.2 & 0.255 & 3 & 131216.60 \\
\hline 5.2 & 0.365 & 3 & 162458.60 \\
\hline
\end{tabular}

Figure 15 shows the mean output voltage for the piezoelectric acoustic generator. The generator has low sensitivity due to the low generated induced voltage as high pressure input was introduced to the acoustic generator. All PEH designs have high sensitivity compared to the piezoelectric acoustic generator. The IDE design shows good performance compared to a simple sandwiched piezoelectric acoustic generator. Although the 
area of the electrode of the piezoelectric acoustic generator is larger than the area for PEH A, this design has more induced voltage compared to the piezoelectric acoustic generator.

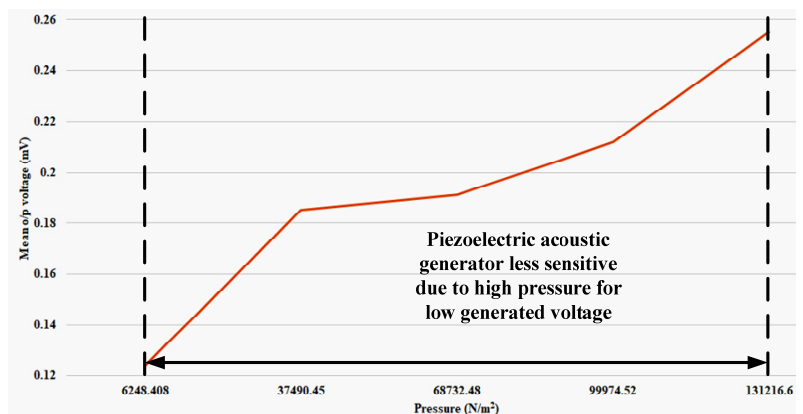

Fig. 15. Plot of mean output voltage versus pressure for piezoelectric acoustic generator

Output voltage from vibration experiment. For vibration experiment, two parts of the results were obtained. Part B.1 shows the results of the generated output voltage versus input frequency of $50 \mathrm{~Hz}$ and part B.2 shows the results of the generated voltage for the given period.

Output voltage versus input frequency. Figure 16 shows the generated output voltage versus the input frequency of $50 \mathrm{~Hz}$ for $\mathrm{PEH} \mathrm{A}$. The generated output voltage generated fluctuated from 0.23 to $0.28 \mathrm{mV}$.

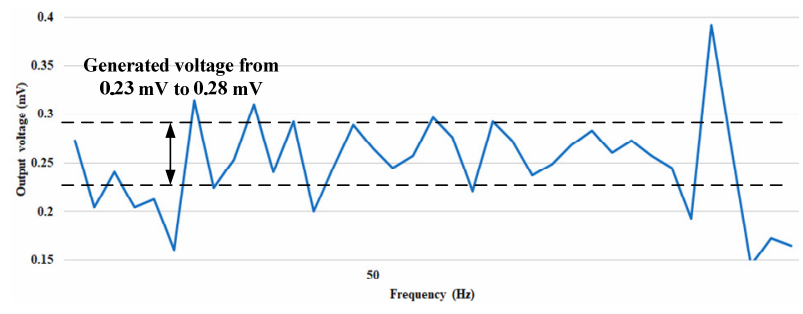

Fig 16. Generated output voltage versus input frequency for PEH A

Figure 17 shows the generated output voltage versus the input frequency of $50 \mathrm{~Hz}$ for $\mathrm{PEH} \mathrm{B}$. The generated output voltage fluctuated from 0.25 to $0.52 \mathrm{mV}$ for the input frequency of $50 \mathrm{~Hz}$. The generated voltage of PEH B consists of two parts: 0.25 to $0.30 \mathrm{mV}$ and 0.45 to $0.50 \mathrm{mV}$.

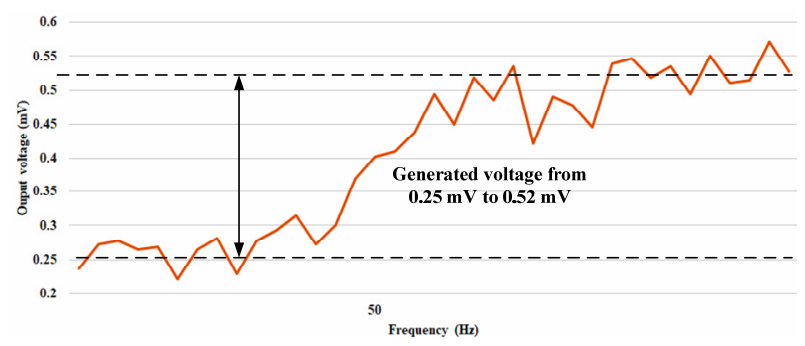

Fig 17. Generated output voltage versus input frequency for PEH B

Figure 18 shows the generated output voltage for $\mathrm{PEH} \mathrm{C}$ for the given input frequency of $50 \mathrm{~Hz}$. The pattern of PEH C output is almost similar to the pattern of PEH B output, where the generated output of PEH C oscillated from 0.28 to $0.55 \mathrm{mV}$. The generated voltage of PEH C also consists of two parts: 0.28 to $0.30 \mathrm{mV}$ and 0.50 to $0.55 \mathrm{mV}$.

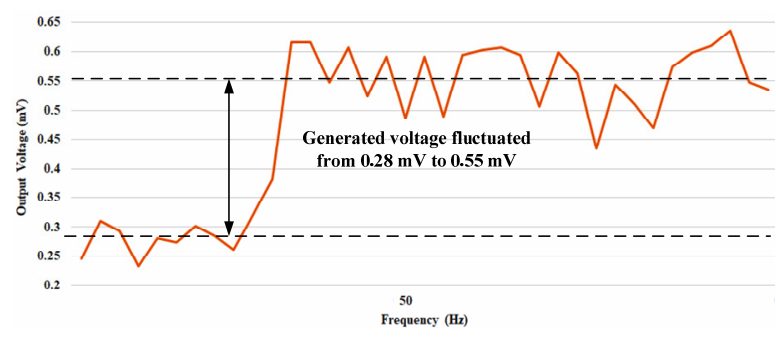

Fig. 18. Generated output voltage versus input frequency for PEH C

All three plotted graphs show that the generated output of load weight is higher compared to vibration. In this experiment, $\mathrm{PEH} \mathrm{C}$ has higher generated voltage than $\mathrm{PEH} \mathrm{B}$ and $\mathrm{PEH} \mathrm{A}$, where $\mathrm{PEH} \mathrm{C}$ recorded the generated voltage of $0.55 \mathrm{mV}$.

Output voltage versus period of time. The results of generated voltage for the period of time are shown in Fig. 19. The generated voltage for all design of PEHs increased significantly at 3 to $4 \mathrm{~min}$. The highest energy stored in the capacitor was generated by $\mathrm{PEH} \mathrm{C}$ with $34560 \mathrm{mV}$.

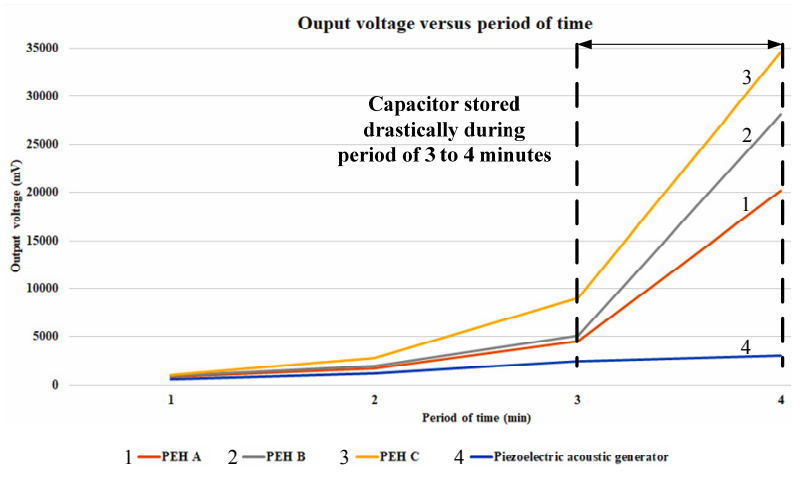

Fig. 19. Generated voltage stored versus period of time

\section{Conclusions.}

1. A new design structure of $\mathrm{PEH}$ using flexible sensing element, PVDF and PCB substrate with IDE circuits were successfully design, fabricated and characterized in this project. Three PEHs with different IDE circuit width were fabricated together with a PVDF sheet and single transparent tape.

2. All designs namely $\mathrm{PEH} \mathrm{A}, \mathrm{PEH} \mathrm{B}$, and $\mathrm{PEH} \mathrm{C}$ were successfully characterized by two experiments namely load and vibration experiments. PEH C generated the highest voltage in load experiment of $2.502 \mathrm{mV}$ for the weight of $5.2 \mathrm{~kg}$. In vibration experiment, $\mathrm{PEH} \mathrm{C}$ generated the highest voltage of $0.55 \mathrm{mV}$ for the input frequency of $50 \mathrm{~Hz}$. $\mathrm{PEH} \mathrm{C}$ also stored the highest voltage of $34560 \mathrm{mV}$ for the time period of $4 \mathrm{~min}$.

3. PEH $\mathrm{C}$ is the best design of an energy harvester if applied for a vibration machine of $50 \mathrm{~Hz}$ or from footsteps in the walking area of an airport. For future recommendations, this device can be installed in the walking area of an airport and used as a free energy source for charging a small electronic device. The device can be placed under the walking area, and then the energy is harvested and stored in a battery bank.

Conflict of interest. The authors declare that they have no conflicts of interest. 


\section{REFERENCES}

1. Zhao L., Tang L., Liang J., Yang Y. Synergy of wind energy harvesting and synchronized switch harvesting interface circuit. IEEE/ASME Transactions on Mechatronics, 2017, vol. 22, no. 2, pp. 1093-1103. doi: https://doi.org/10.1109/tmech.2016.2630732. 2. Shekhar A., Kumaravel V.K., Klerks S., De Wit S., Venugopal P., Narayan N., Bauer P., Isabella O., Zeman M. Harvesting roadway solar energy - performance of the installed infrastructure integrated $\mathrm{PV}$ bike path. IEEE Journal of Photovoltaics, 2018, vol. 8, no. 4, pp. 1066-1073. doi: https://doi.org/10.1109/jphotov.2018.2820998.

3. Camboim M.M., Oliveira V.S., Villarim M.R., Villarim A.W.R., Catunda S.Y.C., Baiocchi O.R., De Souza C.P. An online remote verification system of thermal sources for energy harvesting application. IEEE Transactions on Instrumentation and Measurement, 2020, vol. 69, no. 10, pp. 7962-7973. doi https://doi.org/10.1109/tim.2020.2986105.

4. He W., Zhang J., Yuan S., Yang A., Qu C. A threedimensional magneto-electric vibration energy harvester based on magnetic levitation. IEEE Magnetics Letters, 2017, vol. 8, pp. 1-3, art no. 6104703. doi: https://doi.org/10.1109/lmag.2017.2669300.

5. Todaro M.T., Guido F., Algieri L., Mastronardi V.M., Desmaele D., Epifani G., De Vittorio M. Biocompatible, flexible, and compliant energy harvesters based on piezoelectric thin films. IEEE Transactions on Nanotechnology, 2018, vol. 17, no. 2, pp. 220-230. doi: https://doi.org/10.1109/TNANO.2017.2789300.

6. Khan F.U., Iqbal M. Electromagnetic bridge energy harvester utilizing bridge's vibrations and ambient wind for wireless sensor node application. Journal of Sensors, 2018, vol. 2018, art. no. $3849683 . \quad$ doi https://doi.org/10.1155/2018/3849683.

7. Chaudhuri D., Kundu S. MEMS piezoelectric energy harvester to power wireless sensor nodes for machine monitoring application. 2017 Devices for Integrated Circuit (DevIC), 2017, pp. 584-588. doi https://doi.org/10.1109/devic.2017.8074018.

8. Shin A., Radhakrishna U., Yang Y., Zhang Q., Gu L., Riehl P., Chandrakasan A.P., Lang J.H. A MEMS magnetic-based vibration energy harvester. Journal of Physics: Conference Series, 2018, vol. 1052, p. 012082. doi: https://doi.org/10.1088/1742-6596/1052/1/012082.

9. Rodriguez J.C., Nico V., Punch J. A vibration energy harvester and power management solution for battery-free operation of wireless sensor nodes. Sensors, 2019, vol. 19, no. 17, p. 3776. doi: https://doi.org/10.3390/s19173776.

10. Correia D., Ferreira A. Energy harvesting on airport pavements: state-of-the-art. Sustainability, 2021, vol. 13, no. 11, p. 5893. doi: https://doi.org/10.3390/su13115893.

11. Hosseinkhani A., Younesian D., Eghbali P., Moayedizadeh A., Fassih A. Sound and vibration energy harvesting for railway applications: A review on linear and nonlinear techniques. Energy Reports, 2021, vol. 7, pp. 852-874. doi: https://doi.org/10.1016/j.egyr.2021.01.087.

12. Lee H., Noh M.D., Park Y. Optimal Design of Electromagnetic Energy Harvester Using Analytic Equations. IEEE Transactions on Magnetics, 2017, vol. 53, no. 11, pp. 1-5, art no. 8207605. doi: https://doi.org/10.1109/TMAG.2017.2708130.

13. Cai M., Liao W.-H. Design, modeling, and experiments of electromagnetic energy harvester embedded in smart watch and wristband as power source. IEEE/ASME Transactions on Mechatronics, 2021, vol. 26, no. 4, pp. 2104-2114. doi: https://doi.org/10.1109/tmech.2020.3032536.

How to cite this article:

Mohamad Yusoff A.A., Ahmad K.A., Sulaiman S.N., Hussain Z., Abdullah N. Air cavity-based vibrational piezoelectric energy harvesters. Electrical Engineering \& Electromechanics, 2021, no. 5, pp. 39-45. doi: https://doi.org/10.20998/2074-272X.2021.5.06.
14. Nabavi S., Zhang L. Nonlinear multi-mode wideband piezoelectric MEMS vibration energy harvester. IEEE Sensors Journal, 2019, vol. 19, no. 13, pp. 4837-4848. doi: https://doi.org/10.1109/jsen.2019.2904025.

15. Koven R., Mills M., Gale R., Aksak B. Low-frequency and broadband vibration energy harvesting using base-mounted piezoelectric transducers. IEEE Transactions on Ultrasonics, Ferroelectrics, and Frequency Control, 2017, vol. 64, no. 11, pp. 1735-1743. doi: https://doi.org/10.1109/TUFFC.2017.2739745.

16. Subbaramaiah R., Al-Jufout S.A., Ahmed A., Mozumdar M.M. Design of vibration-sourced piezoelectric harvester for battery-powered smart road sensor systems. IEEE Sensors Journal, 2020, vol. 20, no. 23, pp. 13940-13949. doi: https://doi.org/10.1109/JSEN.2020.3000489.

17. Abasian A., Tabesh A., Rezaei-Hosseinabadi N., Nezhad A.Z., Bongiorno M., Khajehoddin S.A. Vacuum-packaged piezoelectric energy harvester for powering smart grid monitoring devices. IEEE Transactions on Industrial Electronics, 2019, vol. 66, no. 6, pp. 4447-4456. doi: https://doi.org/10.1109/TIE.2018.2860557.

18. Nabavi S., Zhang L. Nonlinear multi-mode wideband piezoelectric MEMS vibration energy harvester. IEEE Sensors https://doi.org/10.1109/JSEN.2019.2904025.

19. Naval S., Sinha P.K., Das N.K., Anand A., Kundu S. Bandwidth increment of piezoelectric energy harvester using multi-beam structure. 2019 Devices for Integrated Circuit (DevIC), 2019, pp. 370-373. doi: https://doi.org/10.1109/devic.2019.8783724.

20. Rubes O., Hadas Z. Design and simulation of bistable piezoceramic cantilever for energy harvesting from slow swinging movement. 2018 IEEE 18th International Power Electronics and Motion Control Conference (PEMC), 2018, pp. 663-668. doi: https://doi.org/10.1109/EPEPEMC.2018.8521846. 21. Lu S., Boussaid F., Law M. Efficient parallel-SSHI interface circuit for piezoelectric energy harvesting. 2013 IEEE 11th International New Circuits and Systems Conference (NEWCAS), 2013, pp. 1-4. doi: https://doi.org/10.1109/NEWCAS.2013.6573658.

Received 15.08.2021

Published 26.10.2021

Ahmad Azrul Mohamad Yusoff ${ }^{1}$, MS,

Khairul Azman Ahmad ${ }^{1}$, Senior Lecturer,

Siti Noraini Sulaiman ${ }^{1}$, Associate Professor,

Zakaria Hussain ${ }^{1}$, Associate Professor,

Noramalina Abdullah', Senior Lecturer,

${ }^{1}$ School of Electrical Engineering, College of Engineering,

Universiti Teknologi MARA,

Cawangan Pulau Pinang, Permatang Pauh,

13500 Pulau Pinang, Malaysia

e-mail: bnc_azrol@yahoo.com.my,

azman062@uitm.edu.my,

sitinoraini@uitm.edu.my,

zakaria183@uitm.edu.my,

${ }^{2}$ School of Electric and Electronic Engineering,

Engineering Campus, Universiti Sains Malaysia,

14300, Nibong Tebal, Pulau Pinang, Malaysia

e-mail: eenora@usm.my (Corresponding author) Journal, 2019, vol. 19, no. 13, pp. 4837-4848. doi:

Accepted 21.09.2021 